\title{
A CLINICAL STUDY OF ACCIDENTAL FINGERNAIL INJURIES TO THE CORNEA IN ALQUWAYIAH GENERAL HOSPITAL, RIYADH REGION, KSA
}

Rajesh Balkrishna Gotekar ${ }^{1}$

${ }^{1}$ Assistant Professor, Department of Ophthalmology, Prakash Institute of Medical Sciences, Urun - Islampur.

\section{ABSTRACT}

\section{BACKGROUND}

Corneal abrasions result from a disruption or loss of cells in the top layer of cornea called the corneal epithelium. Traumatic corneal abrasion can be serious if neglected. Accidental poking of the eye with fingernail induces corneal abrasions. This is one of the most common eye injury that presents to the emergency department and ophthalmology outpatient services. Minor abrasions with no injury to Bowman's membrane heal quickly within 24 hours to 72 hours and there is no scar formation. Corneal abrasions involving Bowman's membrane leave permanent corneal opacity that can impair the vision.

The aim of this study is to analyse fingernail induced injuries of cornea with respect to mode of injury, time, age of injury, time of presentation to the hospital and outcome.

\section{MATERIALS AND METHODS}

This was a retrospective study of 77 patients with accidental fingernail injuries of cornea from May 2014 to April 2015 in Alquwayiah General Hospital, Riyadh Region, KSA. Patient data, mode of injury, time of presentation and outcome was noted and analysed.

\section{RESULT}

The commonest age of presentation was 11 yrs. The commonest mode of corneal injury was accidental fingernail trauma to cornea during play.

\section{CONCLUSION}

This study reinforces that accidental traumatic fingernail induced corneal abrasions treated immediately with proper assessment of corneal injury, adhering to the treatment protocol and good follow-up with patients along with health education of parents and children gives good visual outcome.

\section{KEYWORDS}

Fingernail Injury, Corneal Abrasion, Painful Red Eye, Watering of Eye/s.

HOW TO CITE THIS ARTICLE: Gotekar RB. A clinical study of accidental fingernail injuries to the cornea in Alquwayiah general hospital, Riyadh region, KSA. J. Evolution Med. Dent. Sci. 2017;6(62):4526-4528, DOI: 10.14260/Jemds/2017/979

\begin{abstract}
BACKGROUND
Eyes lie within a protective bony orbit. The exposed anterior $1 / 6^{\text {th }}$ portion of the eye, cornea has other anatomic and functional protections. The eyebrows and eyelashes partially shield the eye from small particles. Eyelids close rapidly and reflexively when ocular danger is sensed.[1] This is menace response, reflex blinking that occurs in response to the rapid approach of an object in order to protect the eyes. ${ }^{[2]}$ Corneal abrasions result from a disruption or loss of cells in the top layer of cornea called the corneal epithelium. Corneal abrasion can be serious if neglected. Minor abrasions with no injury to Bowman's membrane heal quickly within 24 hours to 72 hours and there is no scar formation. Corneal abrasions involving Bowman's membrane leave permanent corneal opacity that can impair the vision. Accidental poking of the eye with Fingernail induces corneal abrasions. This is one of the most common eye injury that presents to the emergency department and ophthalmology outpatient services. [3]
\end{abstract}

Financial or Other, Competing Interest: None.

Submission 21-06-2017, Peer Review 22-07-2017,

Acceptance 28-07-2017, Published 03-08-2017.

Corresponding Author:

Rajesh Balkrishna Gotekar

Sundernagar B. No. 20,

Near Anand Nursing Home,

Sangli-Miraj road, Miraj-416410.

E-mail: dr.rajeshgotekar@gmail.com

DOI: $10.14260 /$ jemds $/ 2017 / 979$
Corneal abrasions account for $10 \%$ of ocular emergency. The incidence of non-penetrating injuries to the eye, which includes corneal abrasions is $1.57 \%$ per year.

Number of male patients treated for corneal abrasions is more than females.[4] Children are more prone to injuries because of their inability to avoid hazards.[5] The infants and children, less than 3 years of age sustain fewer injuries due to close parental supervision.[6]

\section{MATERIALS AND METHODS}

This was a retrospective study of 77 patients with accidental fingernail injury of cornea from May 2014 to April 2015 in Alquwayiah General Hospital, Riyadh Region, KSA. Patient data consisting of name, age, sex, mode of activity at the time of injury, management and outcome was noted and analysed. Study design is retrospective descriptive study.

\section{Inclusion Criteria}

1. All patients having corneal abrasions sustained by fingernail injury.

2. All age group patients.

3. Both males and females included.

Detailed history of mechanism of injury was noted. Common presenting symptoms included pain in the traumatised eye, difficulty in opening the eye, increased tearing, photophobia, swelling of lids and blurring of vision, etc. 
Examination started with instillation of paracaine eye drops to alleviate pain and to have local surface anaesthetic effect. Sometimes Desmarres lid retractor was necessary to separate the lids to examine the condition of cornea. Presterilised commercially available Fluorescein strips were used to confirm the presence corneal abrasion if any. If the patient was able to sit at the slit lamp, visualisation of corneal staining was observed under cobalt blue filtered light. The corneal abrasion will look grass green in colour in cobalt blue filter light. The size of the corneal abrasion in millimetre and site in relation with corneal quadrant, nasal/temporal and superior/inferior was noted. Whenever possible after completing examination, visual acuity was noted on Snellen's chart. We used Landolt's C chart for visual acuity testing.

After confirmation of accidental traumatic fingernail induced corneal abrasion, Moxifloxacin eye drops were prescribed to be instilled in day time; $1 / 2$ hourly for $6 \mathrm{hrs}$. then 3 times/day, chloramphenicol eye applicap was prescribed for bedtime to be squeezed in the affected eye in the lower conjunctival fornix. Patient below 5 yrs. of age were given local Atropine eye ointment (1\%) in the injured eye (in all the 3 patients) by the treating ophthalmologist himself and parents were asked to come for followup the next day. Children above 5 yrs. of age were given cycloplegic eye drops, cyclopentolate to have cycloplegic effect to relieve the spasm of sphincter pupillae. After confirming pupillary dilatation, they were sent home and asked to report in ophthalmology outpatient after 24 hrs. Patching can increase corneal temperature and therefore increase the risk of secondary microbial keratitis after abrasion. It also reduces oxygenation, which can slow re-epithelialization process. Eye patching was not done as it was not recommended.[7,8,9] In the followup after 24 hrs., patient was examined for symptomatic improvement as well as for corneal fluorescein staining to see corneal epithelial healing. Visual acuity testing result were recorded with pinhole as pupil was dilated.

\section{RESULTS}

Males 45 (58.44\%), Females 32 (41.55\%).

\begin{tabular}{|c|c|c|}
\hline Sex & No. of Patients & $\%$ \\
\hline Male & 45 & $58.44 \%$ \\
\hline Female & 32 & $41.55 \%$ \\
\hline Table 1. Sex Distribution of Patients presenting with \\
Fingernail Induced Injury of Cornea \\
\hline
\end{tabular}

\begin{tabular}{|c|c|c|c|}
\hline Age in Yrs. & Male & Female & Total \\
\hline $0-5$ & 01 & 02 & 03 \\
\hline $6-10$ & 22 & 15 & 37 \\
\hline $11-15$ & 13 & 07 & 20 \\
\hline $16-20$ & 05 & 05 & 10 \\
\hline $21-25$ & 03 & 02 & 05 \\
\hline $26-30$ & 00 & 00 & 00 \\
\hline $31-35$ & & & 00 \\
\hline $36-40$ & & 01 & 01 \\
\hline \multirow[t]{3}{*}{$41-45$} & 01 & & 01 \\
\hline & 45 & 32 & 77 \\
\hline & $58.44 \%$ & $41.55 \%$ & $100 \%$ \\
\hline
\end{tabular}

Average age of presentation combining both male and female was 11.67 yrs.

Males 11.8 yrs.

Females 11.5 yrs.

All patients were treated as an outpatient. No complications were encountered in our 77 patients treated at the hospital.

\begin{tabular}{|c|c|}
\hline $\begin{array}{c}\text { Number of Patients } \\
\text { /Eyes (n= 77) }\end{array}$ & $\begin{array}{c}\text { Size of the Fingernail Induced } \\
\text { Corneal Abrasion }\end{array}$ \\
\hline $45(58.44 \%)$ & $\begin{array}{c}\text { About } 4 \text { mm linear/oval shaped } \\
\text { corneal abrasion below the } \\
\text { inferior pupillary margin }\end{array}$ \\
\hline $30(38.96 \%)$ & $\begin{array}{c}\text { About } 5 \text { mm in size and semicircular } \\
\text { in shape at temporal aspect of cornea }\end{array}$ \\
\hline $02(2.59 \%)$ & $\begin{array}{c}\text { About } 6 \text { mm or more in diameter } \\
\text { covering pupillary area }\end{array}$ \\
\hline \multicolumn{2}{|c|}{ Table 3. Number of Patients and } \\
Size of the Corneal Abrasion
\end{tabular}

\begin{tabular}{|c|c|c|}
\hline $\begin{array}{c}\text { No. of } \\
\text { Patients }\end{array}$ & $\begin{array}{c}\text { First Time Examination of } \\
\text { the Injured Eye in OPD/ER }\end{array}$ & $\begin{array}{c}\text { After Healing of } \\
\text { Corneal Abrasion } \\
\text { after 1 Week }\end{array}$ \\
\hline 02 & Finger Counting - 6/60 & $6 / 12-6 / 9$ \\
\hline 10 & $6 / 36$ & $6 / 9$ \\
05 & $6 / 18$ & $6 / 9$ \\
\hline 30 & $6 / 12$ & $6 / 6$ \\
10 & $6 / 9$ & $6 / 6$ \\
\hline 17 & $6 / 6$ & $6 / 6$ \\
\hline 74 & \multicolumn{2}{|c|}{ Table 4. Visual Acuity at Time of } \\
\hline \multicolumn{2}{|c|}{ First Exam and Followup after 1 Week } \\
\hline \multicolumn{2}{|c}{}
\end{tabular}

Out of 77 patients, we could record visual acuity of 74 patients on Snellen's chart. We used Landolt's 'C' chart. 40 patients (51.94\%) were having a good visual acuity of $6 / 12$ $6 / 9$ range.

15 patients $(19.48 \%)$ were having a visual acuity of $6 / 36$ $-6 / 18$ range.

3 patients (3.8\%) were of age range below 3 yrs., so not possible to record visual acuity on Snellen's vision chart.

\begin{tabular}{|c|c|c|}
\hline $\begin{array}{c}\text { Time of } \\
\text { Presentation after } \\
\text { Injury }\end{array}$ & $\begin{array}{l}\text { In Emergency } \\
\text { Services } \\
4.31 \mathrm{pm}-7.30 \\
\text { am }\end{array}$ & $\begin{array}{c}\text { In Outpatient } \\
\text { Services } \\
7.31 \text { am }-4.30 \\
\text { pm }\end{array}$ \\
\hline $\begin{array}{c}\text { Within } 3 \text { hrs. of } \\
\text { injury ( } 37 \text { patients) }\end{array}$ & $15(40.54 \%)$ & $22(55.0 \%)$ \\
\hline $\begin{array}{c}\text { Within } 12 \text { hrs. of } \\
\text { injury (15 patients) }\end{array}$ & 05 (13.51 \%) & $10(25.0 \%)$ \\
\hline $\begin{array}{c}\text { From } 12 \text { hrs. }-24 \text { hrs. } \\
\text { (18 patients) }\end{array}$ & $13(35.13 \%)$ & $05(12.5 \%)$ \\
\hline $\begin{array}{c}\text { More than } 24 \mathrm{hrs} . \\
\text { (07 patients) }\end{array}$ & $04(10.81 \%)$ & $03(7.5 \%)$ \\
\hline Total (77 patients) & $37(100 \%))$ & $40(100 \%)$ \\
\hline \multicolumn{3}{|c|}{$\begin{array}{c}\text { Table 5. Time of Presentation to the Emergency } \\
\text { Department and Ophthalmology Outpatient } \\
\text { Services at the ALQ Hospital }\end{array}$} \\
\hline
\end{tabular}

Out of 77 patients, 37 patients (48.05\%) attended emergency services and 40 patients $(51.94 \%)$ attended in outpatient services. Whatever the time of injury to the eyes, the parents sought the medical services. Only 07 patients $(9.09 \%)$ sought medical treatment after 24 hours. They have 
consulted primary health services first and then came for specialist's opinion.

Table 5- Eye involved in fingernail induced corneal abrasion.

In all among the 77 patients, we found 55 patients $(71.42 \%)$ got injury to the left eye.

22 patients $(28.57 \%)$ got injured their right eye.
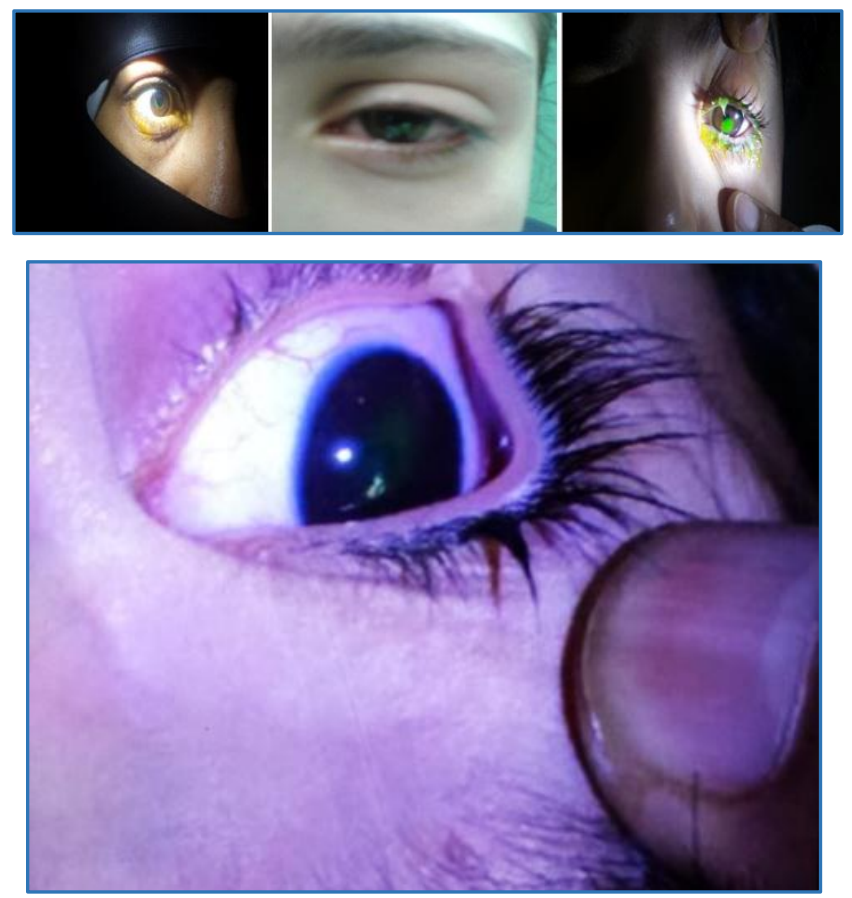

\section{DISCUSSION}

Fingernail induced injury to cornea is a routine emergency on call to attend to emergency room for an ophthalmologist apart from attending RTA, blunt trauma to eye, alleged assault and corneal foreign body removal call. It was observed that people are aware to take ophthalmologist's opinion as early as possible. Alquwayiah General Hospital was a referral hospital and the 350-bedded hospital on Riyadh- Makka Madinah road. People in the vicinity of around 200 - $300 \mathrm{kms}$ were visiting this hospital for speciality opinion. We found many traumatic corneal injuries by accidental fingernail induced injury on Fridays and Saturdays (holidays in KSA). Parents with their kid/child reached within $3 \mathrm{hrs}$. after the eye injury in emergency services time $4.31 \mathrm{pm}$ - $7.30 \mathrm{am}(\mathrm{n}=40.54 \%)$ and in outpatient services at the time of 7.31 am to $4.30 \mathrm{pm}(\mathrm{n}=55.0 \%)$.

The size of the corneal abrasion was noted in millimetres. The site was also recorded in accordance with corneal quadrant as superior/inferior and nasal/temporal. We saw more number of fingernail induced corneal abrasions in inferotemporal quadrant of cornea. It may be attributed to Bell's eye phenomenon, turning eyeballs upwards while eyes getting closed and poking of eyes from temporal aspect with untrimmed fingernails during play and/or fist of anger.

Corneal abrasions are often painful because of exposure of corneal nerves. The epithelium has been denuded from an area of cornea, leaving the corneal nerve endings exposed.

After the use of antibiotic eye drop, moxifloxacin and cycloplegics and hydroxymethylcellulose eye drops reepithelialisation, healing was observed in $24 \mathrm{hrs}$. In all the patients total healing of the corneal abrasion was observed in a week, Sabri and Colleagues reported that topical antibiotics and cycloplegics were the most commonly prescribed treatments.[10]

\begin{tabular}{|c|c|c|}
\hline & $\begin{array}{c}\text { In Our } \\
\text { Study }\end{array}$ & $\begin{array}{c}\text { Study by Lin } \\
\text { YB, Gardiner } \\
\text { MF }\end{array}$ \\
\hline $\begin{array}{c}\text { No. of patients had traumatic } \\
\text { fingernail injury in 1 yr. }\end{array}$ & 77 & 99 \\
\hline $\begin{array}{c}\text { No. of males with corneal } \\
\text { abrasions by fingernail } \\
\text { trauma }\end{array}$ & $45(58.44 \%)$ & $55(56 \%)$ \\
\hline $\begin{array}{c}\text { No. of females with corneal } \\
\text { abrasions by fingernail } \\
\text { trauma }\end{array}$ & $32(41.55 \%)$ & $44(44 \%)$ \\
\hline $\begin{array}{c}\text { Complications observed in the } \\
\text { patients during treatment }\end{array}$ & 00 & $07(7.07 \%)$ \\
\hline $\begin{array}{c}\text { Average age of presentation } \\
\text { of patients in the study }\end{array}$ & 11.4 yrs. & $29.4 \mathrm{yrs}$. \\
\hline \multicolumn{2}{|c|}{$\begin{array}{c}\text { Table 6. Comparison of Our Study } \\
\text { with the Study by Lin YB, Gardiner MF }\end{array}$} \\
\hline \multicolumn{2}{|c|}{}
\end{tabular}

\section{CONCLUSION}

Most fingernail injuries of cornea in children are preventable. This reflects the importance of health education about care of eyes, adult supervision and application of appropriate preventive measures that are necessary for reducing the incidence and severity of trauma.

\section{Recommendations}

The parents, caretakers and teachers have an important role to play in prevention of these injuries. Health education in schools and home to increase awareness about importance of trimming of fingernails in vulnerable school going children should be done in order to reduce ocular morbidity. Teaching of parents about keeping the fingernails of infants clipped short.

\section{REFERENCES}

[1] Wilson SA, Last A. Management of corneal abrasions. Am Fam Physician 2004;70(1):123-8.

[2] Adler FH. Physiology of the eye: clinical application. $2^{\text {nd }}$ edn. Mosby 1953:P 23.

[3] Lin YB, Gardiner MF. Fingernail-induced corneal abrasions: case series from an ophthalmology emergency department. Cornea 2014;33(7):691-5.

[4] Peter HS. Anterior segment trauma. In: Principles and practice of ophthalmology. Albert DM (edr). Philadelphia: saunders 2000.

[5] Negral AD, Thylefors B. The global impact of eye injuries. Ophthalmic epidemiology 1998;5(3):143-69.

[6] Montanes CB, Cueva MC, Garcia SC, et al. Eye injuries in childhood. Ann Esp Pediatrics 1998;48:625-30.

[7] Le Sage N, Verreault R, Rochette L. Efficacy of eye patching for traumatic corneal abrasions: a controlled clinical trial. Ann Emerg Med 2001;38(2):129-34.

[8] Michael JG, Hug D, Dowd MD. Management of corneal abrasion in children: a randomized clinical trial. Ann Emerg Med 2002;40(1):67-72.

[9] Flynn CA, D'Amico F, Smith G. Should we patch corneal abrasions? A meta-analysis. J Fam J Fam Pract 1998;47(4):264-70.

[10] Sabri K, Pandit JC, Thaller VT, et al. National survey of corneal abrasion treatment. Eye 1998;12 (Pt 2):27881. 